\title{
PENERAPAN MODEL PEMBELAJARAN TEAMS GAMES TOURNAMENT UNTUK MENINGKATKAN KEAKTIFAN DAN HASIL BELAJAR IPA
}

\author{
Wahyu Astuti ${ }^{1}$, , Firosalia Kristin ${ }^{2}$ \\ 1 Universitas Kristen Satya Wacana \\ 2 Universitas Kristen Satya Wacana
}

\begin{abstract}
Abstrak
Penelitian ini bertujuan untuk mengetahui dan mendeskripsikan langkah-langkah model pembelajaran Teams Games Tournament (TGT) dalam meningkatkan keaktifan dan hasil belajar IPA siswa kelas V SD. Subyek penelitian adalah siswa kelas V SD N Tegalrejo 01 yang berjumlah 39 siswa. Jenis penelitian yang digunakan dalam penelitian ini adalah Penelitian Tindakan Kelas yang dilaksanakan dalam II siklus yaitu siklus I dan siklus II. Teknik pengumpulan data yang digunakan dalam penelitian ini adalah teknik tes dan non tes. Analisis data dilakukan dengan menggunakan analisis deskriptif komparatif. Keaktifan dan hasil belajar siswa mengalami peningkatan yang berarti. Keaktifan siswa pra siklus $28,20 \%$, siklus I $58,97 \%$ dan siklus II menjadi 71,79\%. Hasil belajar ranah kognitif pra siklus $61,54 \%$, pada siklus I menjadi $82,05 \%$ dan pada siklus II menjadi 92,31\%.. Hasil penelitian dapat disimpulkan bahwa penerapan model pembelajaran Teams Games Tournament (TGT) dapat meningkatkan keaktifan dan hasil belajar IPA siswa kelas V SD N Tegalrejo 01.
\end{abstract}

\author{
Keywords: \\ Model TGT, \\ Keaktifan, \\ Hasil Belajar
}

\section{Pendahuluan}

Kegiatan utama dalam proses pendidikan di sekolah adalah kegiatan pembelajaran. Pembelajaran yang ada merupakan penentu keberhasilan dalam mencapai tujuan pendidikan. Siswa yang belajar diharapkan mengalami perubahan baik dalam bidang pengetahuan, pemahaman, keterampilan, nilai dan sikap. Hal ini sesuai dengan pendapat Fontana (dalam Ar.,Suherman.,dkk,2003) yang menyatakan bahwa proses perubahan tingkah laku individu relative tetap sebagai hasil dari pengalaman.

Sistem pembelajaran di Sekolah Dasar memiliki beberapa cakupan seperti: kurikulum, RPP, metode pembelajaran, dan karakteristik siswa yang berbeda-beda. Dalam KTSP guru ditempatkan sebagai fasilitator dan mediator yang membantu agar proses belajar siswa berjalan dengan baik. Sehingga pada implementasi kurikulum, kegiatan belajar mengajar tidak didominasi oleh guru, melainkan siswa yang lebih aktif selama proses pembelajaran. Keberhasilan proses pembelajaran tidak terlepas dari kemampuan guru dalam mengembangkan model-model pembelajaran yang berorientasi pada peningkatan intensitas keterlibatan siswa secara efektif dalam pembelajaran. Oleh karena itu, guru sebagai pendidik harus bisa memilih metode maupun model pembelajaran yang tepat agar tujuan pembelajaran dapat tercapai.

Berdasarkan observasi awal di SD N Tegalrejo 01 Kota Salatiga ditemukan bahwa dalam pembelajaran IPA, guru masih dominan menggunakan model pembelajaran yang berpusat pada guru (Teacher Centered Learning) dimana pembelajaran bersifat satu arah sehingga siswa tidak memiliki kesempatan untuk mengungkapkan ide dan menggali kemampuan dalam diri siswa. Guru hanya menyampaikan materi di depan kelas, sedangkan siswa pasif. Akibat dari kebiasaan tersebut partisipasi siswa rendah, kerja sama dalam kelompok tidak optimal, kegiatan belajar mengajar tidak efisien dan pada akhirnya prestasi belajar siswa rendah.

Hasil belajar siswa rendah dibuktikan dengan ketuntasan belajar siswa pada kondisi awal sebanyak 15 siswa $(61,54 \%)$ masih belum mencapai kriteria ketuntasan minimal (KKM). Selain itu keaktifan belajar siswa juga relatif rendah ditandai dengan: 1) siswa cenderung pasif, kurang partisipasi dalam mengikuti pembelajaran, 2) kerja kelompok kurang optimal, 3) siswa kurang berani mengungkapkan ide maupun pendapat. Dari berbagai permasalahan diatas, maka dapat ditarik kesimpulan bahwa penyebab utama rendahnya hasil belajar siswa adalah proses belajar mengajar masih 
berpusat pada guru (Teacher Centered Learning) sehingga siswa tidak terlibat aktif dalam pembelajaran. Oleh karena itu dibutuhkan peran guru untuk dapat menerapkan pembelajaran yang melibatkan partisipasi siswa sehingga kegiatan belajar mengajar menjadi menyenangkan.

Berhasil tidaknya suatu pembelajaran di sekolah bergantung pada keterlibatan siswa dan penggunaan model pembelajaran dalam proses belajar mengajar. Penggunaan model pembelajaran sangat diperlukan dalam proses pembelajaran. Dalam hal ini adalah untuk menarik perhatian siswa, minat serta keterlibatan siswa, sehingga siswa mampu berpartisipasi secara aktif. Dengan keaktifan tersebut maka siswa akan lebih mandiri dan mampu membangun konsep dengan pengalamannya secara langsung. Dengan proses tersebut harapannya adalah siswa mampu menyelesaikan permasalahan dalam kehidupan sehari-hari.

Melihat permasalahan diatas, maka perlu diterapkan suatu model pembelajaran yang dapat meningkatkan partisipasi siswa dalam proses pembelajaran yaitu dengan menerapkan model pembelajaran kooperatif tipe Teams Games Tournamen (TGT). Menurut Hamdani (2010:92) Pembelajaran kooperatif tipe TGT adalah salah satu tipe atau model pembelajaran kooperatif yang mudah diterapkan, melibatkan aktivitas seluruh siswa tanpa ada perbedaan status, melibatkan peran siswa sebagai tutor sebaya, dan mengandung unsur permainan dan reinforcement. Proses pembelajaran berlangsung dalam kelompok-kelompok kecil dengan fasilitator teman sejawat yang dapat membuat siswa aktif karena menggunakan sistem game akademik. Komponen TGT meliputi presentasi kelas, belajar kelompok, game, turnamen dan penghargaan kelompok. Dengan pembelajaran TGT di kelas, menuntut siswa aktif dalam pembelajaran baik secara fisik, mental maupun emosional guna mencapai hasil belajar yang optimal.

IPA ialah ilmu yang berhubungan dengan gejala alam yang disusun secara sistematis berdasarkan hasil pengamatan dan percobaan yang dikumpulkan dan disusun secara teratur dimana pengetahuan itu saling berkaitan sehingga antara satu dengan lainnya merupakan satu kesatuan yang utuh (Powler dalam Usman Samatowa, 2011: 3). Selanjutnya menurut Folwer (dalam Trianto :2014:136) "IPA ialah pengetahuan yang sistematis yang dirumuskan, yang berhubungan dengan gejala-gejala kebendaan dan didasarkan terutama atas pengamatan dan dedukasi".

Menurut Usman Samatowa (2011:4) IPA mampu melatih anak untuk berpikir kritis dan objektif, sehingga IPA bermanfaat bagi suatu bangsa kerena IPA merupakan dasar teknologi. Hal tersebut sejalan dengan yang tertuang dalam KTSP Standar Isi 2006, pembelajaran IPA diharapkan dapat menjadi wahana bagi peserta didik untuk mempelajari diri sendiri dan alam sekitar, serta prospek pengembangan lebih lanjut dalam menerapkannya dalam kehidupan sehari-hari.

Pembelajaran IPA di SD, hendaknya tidak hanya fokus pada pencapaian akademik saja, akan tetapi harus mengembangkan keterampilan proses yang nantinya dapat melatih siswa untuk berfikir kritis, kreatif, menemukan sendiri konsep, dan sikap ilmiah yang nantinya dapat berpengaruh terhadap proses pendidikan maupun produk pendidikan.

TGT merupakan salah satu model pembelajaran yang bisa disebut dengan Pertandingan Permainan Team yang dikembangkan oleh David De Vries dan Keath Edwart, dalam Fathurrohman (2015:55) menjelaskan bahwa pembelajaran kooperatif tipe TGT ialah salah satu dari model pembelajaran kooperatif yang menempatkan siswa dlam kelompok belajar beranggotakan 3-6 orang dimana anggota kelompok dipilih secara heterogen.

Aktivitas belajar dengan model TGT memungkinkan siswa dapat belajar lebih rileks disamping menumbuhkan tanggung jawab, kerjasama, persaingan sehat, dan keterlibatan belajar. Dengan adanya kompetisi kelompok harapannya adalah siswa dapat saling berinterkasi, mampu bekerja sama dan termotivasi untuk menjadi kelompok terbaik. Dengan demikian siswa lebih antusias dalam mengikuti pembelajaran

Sitaks (langkah-langkah) dalam pembelajaran model pembelajaran TGT ada 4 yaitu penyajian kelas, belajar bersama kelompok, melakukan tournament, dan penghargaan kelompok. Kelompok terdiri dari 3 hingga 6 orang. Dalam pemilihan kelompok, anggota yang dipilih harus heterogen sesuai dengan jenis kelamin, suku, dan prestasi akademik yang dimiliki siswa. Pemilihan anggota kelompok yang heterogen diharapkan mampu membuat siswa menajdi ebih bertanggung jawab dan mampu bekerjasama dalam kelompok. Turnamen yang dilakukan dibuat dengan permainan yang menggunakan kuis berisi pertanyaan yang berhubungan dengan materi untuk mengetahi tingkat pemahaman siswa.

Adapun langkah-langkah model pembelajaran TGT menurut Slavin dalam Kadir (2013) sebagai berikut: (1) Guru mengajar seperti biasa. (2) Siswa-siswa belajar dalam kelompok yang heterogen. (3) Masing-masing siswa menuju kemeja turnamen untuk bertanding. Setiap meja turnamen terdiri dari wakil dari tiap kelompok, memiliki kemampuan yang sama. (4) Setelah pertandingan selesai, semua siswa kembali ke kelompok masing-masing. (5) Guru mengumumkan dan memberi penghargaan kepada kelompok yang menjadi juara. 
Menurut De Vries dan Slavin dalam Kadir (2013) mengemukakan bahwa kelebihan dan kekurangan model pembelajaran TGT. Kelebihannya adalah: (1) Melatih siswa mengungkap atau menyampaikan gagasan/idenya. (2) Melatih siswa untuk menghargai pendapat atau gagasan orang lain. (3) Menumbuhkan rasa tanggung jawab sosial

(4) Melatih siswa untuk mampu mengaktualisasikan dan mengoptimalkan dirinya menghadapi perubahan yang terjadi. (5) Melatih siswa untuk mampu mengembangkan potensi individu yang berhasil guna dan berdaya guna, kreatif dan bertanggung jawab.

Kekurangannya antara lain: (1) Kadang hanya beberapa siswa yang aktif dalam kelompoknya. (2) Kendala teknis, misalnya masalah tempat duduk kadang sulit atau kurang mendukung untuk diatur keanggotaan kelompok. (3) Membutuhkan banyak waktu.

Sedangkan menurut Suarjana dalam Sudarti (2015), yang merupakan kelebihan model pembelajaran TGT adalah: (1) lebih meningkatkan pencurahan waktu untuk tugas. (2) Mengedepankan penerimaan terhadap perbedaan individu. (3) Dengan waktu yang sedikit dalam menguasai materi yang mendalam. (4) Proses belajar mengajar berlangsung dengan keaktifan dari siswa. (5) Motivasi belajar lebih tinggi. (6) Mendidik siswa untuk berlatih bersosialisasi dengan orang lain. (7) Hasil belajar lebih baik. (8) Meningkatkan kebaikan budi, kepekaan dan tolernsi. Adapun kelemahannya adalah sebagai berikut: (1) Bagi guru, Sulitnya pengelompokkan siswa yang mempunyai kemampuan heterogen dari sisi akademis. Kemampuan ini akan bisa diatasi jika guru bertindak sebagai pemegang kendali teliti dalam menetukan pembagian kelompok. Waktu yang dihabiskan oleh siswa untuk diskusi cukup banyak sehingga melewati waktu yang sudah ditentukan. (2) Bagi siswa, Masih adanya siswa berkemampuan tinggi kurang terbiasa dan sulit memberikan penjelasan kepada siswa lainnya.

Keaktifan belajar dapat diartikan sebagai suatu kegiatan yang dilakukan oleh siswa dalam pelaksanaan proses pembelajaran, dimana siswa bekerja atau berperan aktif dalam pembelajaran di kelas, sehingga dengan demikian siswa tersebut memperoleh pengalaman, pengetahuan, pemahaman dan aspek-aspek lain tentang apa yang telah dilakukan. Keaktifan yang dilakukan di kelas terjadi bila ada kegiatan yang dilakukan guru dan siswa. Yang dimaksud keaktifan belajar dalam hal ini adalah keaktifan yang bersifat fisik maupun mental dalam proses kegiatan belajar mengajar guna menunjang keberhasilan proses belajar mengajar (Maharani \& Kristin, 2017).

Menurut Mudjiono dan Dimyati (2009) keaktifan siswa dalam peristiwa pembelajaran mengambil beranekaragam bentuk kegiatan, dari kegiatan fisik yang mudah diamati sampai kegiatan psikis yang sulit diamati. Kegiatan fisik yang dapat diamati diantaranya dalam bentuk kegiatan membaca, mendengarkan, menulis, meragakan dan menggunakan pengetahuan untuk memecahkan masalah yang dihadapi, menyimpulkan percobaan, membandingkan suatu konsep dan sebagainya. Pengukuran keaktifan menggunakan teknik penilaian non tes. Teknik penilaian non tes berupa lembar observasi yang digunakan untuk menilai keaktifan siswa selama mengikuti pembelajaran.

Menurut Aunurrahman (2010) belajar merupakan usaha sadar yang dilakukan individu dalam perubahan tingkah laku baik melalui latihan dan pengalaman yang menyangkut beberapa aspek, meliputi aspek kognitif, afektif, dan psikomotorik untuk memperoleh tujuan tertentu. Tujuan dari proses belajar adalah pengetahuan serta pengalaman menuju perubahan tingkah laku dan kemampuan bereaksi yang bersifat permanen. Hal tersebut sejalan dengan pendapat Slameto (2003) yang menyatakan bahwa hasil belajar yaitu perubahan yang terjadi dalam diri seseorang, berkesinambungan dn tidak statis. Satu perubahan yang terjadi akan menyebabkan perubahan berikutnya dan akan berguna bagi kehidupan atau proses belajar berikutnya. Sedangkan menurut Purwanto (2011) hasil belajar merupakan hasil yang diperoleh akibat dari suatu aktivitas yang dilakukan oleh seseorang. Hasil belajar berarti hasil yang diperoleh seseorang dari aktivitas yang dilakukan dan mengakibatkan terjadinya perubahan tingkah laku.

Slameto (2003) menyatakan bahwa faktor-faktor yang mempengaruhi hasil belajar digolongkan menjadi dua, yaitu: (1) Faktor internal adalah faktor yang berasal dari diri siswa. Faktor internal ini terdiri dari tiga faktor diantaranya adalah: (a) Jasmaniah, misalnya: kesehatan dan cacat tubuh. (b) Psikologis, misalnya: intelegensi, perhatian, minat, bakat, motif, kematangan, dan kesiapan. (c) Kelelahan. (2) Faktor Eksternal, (a) Keluarga, misalnya: cara orang tua mendidik, relasi antar anggota keluarga, suasana rumah, keadaan ekonomi keluarga, pengertian orang tua, dan latar belakang kebudayaan. (b) Sekolah, misalnya: metode mengajar, kurikulum, relasi guru dengan siswa, disiplin sekolah, alat pelajaran, waktu sekolah, standar pelajaran diatas ukuran, keadaan gedung, model pembelajaran, metode belajar, dan tugas rumah. (c) Masyarakat, misalnya: kegiatan-kegiatan siswa dalam masyarakat, media massa, teman bergaul, bentuk kehidupan masyarakat. 


\section{Metode Penelitian}

Penelitian ini merupakan penelitian tindakan kelas (PTK) yang dilaksanakan dalam dua siklus yaitu siklus I dan siklus II. Kemmis dan Mc Taggart mengatakan bahwa penelitian tindakan merupakan suatu bentuk penelitian refleksi diri untuk memperbaiki praktik yang dilakukan sendiri. Setiap siklus terdiri dari empat tahap yaitu perencanaan, tindakan, observasi, dan refleksi.Subyek penelitian adalah siswa kelas V SD N Tegalrejo 01 yang berjumlah 39 siswa. Pemilihan subyek dalam penelitian ini didasarkan pada pertimbangan bahwa subyek tersebut mempunyai permasalahan yang telah teridentifikasi pada observasi awal.

Data yang dikumpulkan dalam penelitian ini meliputi data hasil observasi berupa lembar keaktifan siswa, hasil penilaian aspek kognitif, aspek afektif dan aspek psikomotor serta wawancara dan observasi mengenai kegiatan pembelajaran yang berlangsung di kelas.Teknik pengumpulan data yang digunakan dalam penelitian ini adalah teknik tes dan non tes. Menurut Slameto (2015) terdapat dua macam alat pengukuran yaitu tes dan non tes. (a) Teknik Tes adalah serentetan pertanyaan atau latihan serta alat lain yang digunakan untuk mengukur keterampilan, pengetahuan intelegensi, kemampuan atau bakat yang dimiliki oleh individu atau kelompok. (b) Teknik Nontes adalah cara pengumpulan data dengan tidak menggunakan alat-alat baku, dengan demikian tidak bersifat mengukur dan tidak diperoleh angka-angka sebagai hasil pengukuran. Teknik nontes terdiri dari: observasi, wawancara, studi dokumentasi, catatan lapangan. Teknik analisis data dilakukan dengan menggunakan analisis deskriptif komparatif dengan membandingkan kondisi pada pra siklus, siklus I dan siklus II untuk mengetahui peningkatan hasil belajar.

\section{Hasil Dan Pembahasan}

\section{Hasil}

Tabel 1. Analisis Perbandingan Keaktifan Belajar Siswa Kondisi Awal, Siklus I dan Siklus II

\begin{tabular}{cccccccc}
\hline No & Kategori & \multicolumn{2}{l}{ Kondisi Awa } & \multicolumn{2}{c}{ Siklus I } & \multicolumn{2}{c}{ Siklus II } \\
\hline & & F & Presen & F & Presen & F & Presen \\
& & & $(\%)$ & & $(\%)$ & $(\%)$ \\
\hline 1 & Sangat aktif & 0 & $0 \%$ & 7 & $17,95 \%$ & 11 & $28,20 \%$ \\
2 & A.ktif & 11 & $28,20 \%$ & 23 & $58,97 \%$ & 28 & $71,79 \%$ \\
3 & Cukup aktif & 19 & $48,72 \%$ & 9 & $23,08 \%$ & 0 & $0 \%$ \\
4 & Kurang aktif & 9 & $23,08 \%$ & 0 & $0 \%$ & 0 & $0 \%$ \\
& Jumlat & 39 & $100 \%$ & 39 & $100 \%$ & 39 & $100 \%$ \\
\hline
\end{tabular}

Tabel 1 merupakan data perbandingan keaktifan belajar siswa pada kondisi awal, siklus I dan siklus II. Pada kondisi awal data menunjukkan terdapat 9 siswa $(23,08 \%)$ yang kurang aktif, pada siklus I dan siklus II sudah tidak ada siswa yang kurang aktif. 19 siswa $(48,72 \%)$ cukup aktif, pada siklus I menjadi 9 siswa (23,08\%) yang cukup aktif, dan pada siklus II tidak sudah ada siswa yang cukup aktif. Terdapat 11 siswa (28,20\%) yang aktif pada siklus I meningkat menjadi 23 siswa (58,97\%) yang aktif kemudian meningkat lagi pada siklus II menjadi 28 siswa (71,95\%) aktif. Pada kondisi awal belum terdapat siswa yang sangat aktif, pada siklus I meningkat menjadi 7 siswa $(17,95 \%)$ yang sangat aktif dan pada siklus II mengalami peningkatan menjadi 11 siswa (28,20\%) sangat aktif. Hal tersebut menunjukkan adanya peningakatan keaktifan belajar siswa dari kondisi awal, siklus I dan siklus II. Dengan demikian terbukti bahwa dengan menggunakan model pembelajaran Teams Games Tournament (TGT) dapat meningkatkan keaktifan belajar siswa SD N Tegalrejo 01.

Tabel 2. Analisis Perbandingan Ketuntasan Belajar Ranah Kognitif Siswa Pra Siklus, Siklus I dan Siklus II

\begin{tabular}{|c|c|c|c|c|c|c|c|}
\hline \multirow[t]{2}{*}{ No } & \multirow[t]{2}{*}{ Ketuntasan } & \multicolumn{2}{|c|}{ Pra SikJus } & \multicolumn{2}{|c|}{ Siklus I } & \multicolumn{2}{|c|}{ SikJus II } \\
\hline & & $\mathrm{F}$ & Persen & $\mathrm{F}$ & Persen & $\mathrm{F}$ & Persen \\
\hline 1 & Tuntas. & 24 & $61,54 \%$ & 32 & $82,05 \%$ & 36 & $92,31 \%$ \\
\hline \multirow[t]{5}{*}{2} & Belum Tuntas & 15 & $38,46 \%$ & 7 & $17,95 \%$ & 3 & $7,69 \%$ \\
\hline & Jumbab & 39 & 100 & & & 39 & 100 \\
\hline & Nilai Rata-rata & \multicolumn{2}{|c|}{70,12} & \multicolumn{2}{|c|}{81,15} & \multicolumn{2}{|c|}{90,25} \\
\hline & Nilai Tertinggi & \multicolumn{2}{|c|}{85} & \multicolumn{2}{|c|}{95} & \multicolumn{2}{|c|}{100} \\
\hline & Nilai Terendah & \multicolumn{2}{|c|}{42} & \multicolumn{2}{|c|}{55} & \multicolumn{2}{|c|}{60} \\
\hline
\end{tabular}


Tabel 2 menyajikan hasil belajar ranah kognitif IPA pra siklus, siklus I dan siklus II. Data menunjukkan pada kondisi awal terdapat 24 siswa (61,54\%) tuntas dan masih terdapat 15 siswa $(38,46 \%)$ belum tuntas pada siklus I mengalami peningkatan menjadi 32 siswa (82,05\%) tuntas dan 7 siswa $(17,95 \%)$ belum tuntas. Terjadi peningkatan kembali pada siklus II menjadi 36 siswa $(92,31 \%)$ tuntas dan hanya 3 siswa (7,69\%) yang belum tuntas. Nilai rata rata meningkat dari 70,12 pada siklus I menjadi 81,15 dan pada siklus II menjadi 90,25. Nilai tertinggi dan nilai terendah juga mengalami peningkatan. Pada kondisi awal nilai tertinggi 85 meningkat menjadi 95 pada siklus I dan meningkat kembali menjadi 100 pada siklus II. Nilai terendah 42 menjadi 55 dan meningkat menjadi 60. Dari pra siklus, siklus I dan siklus II menunjukkan adanya peningkatan hasil belajar ranah kognitif.

Tabel 3. Analisis Perbandingan Ketuntasan Hasil Belajar Ranah Kognitif IPA Siklus I dan Siklus II

\begin{tabular}{|c|c|c|c|c|c|}
\hline \multirow[t]{2}{*}{ No } & \multirow[t]{2}{*}{ Ketuntasan } & \multicolumn{2}{|c|}{ Siklus I } & \multicolumn{2}{|c|}{ Siklus II } \\
\hline & & $\begin{array}{l}\text { Nilai Rata- } \\
\text { rata }\end{array}$ & $\begin{array}{c}\text { Nilai } \\
\text { Klasikal }\end{array}$ & $\begin{array}{c}\text { Nilai } \\
\text { Rata-rata }\end{array}$ & $\begin{array}{c}\text { Nilai } \\
\text { Klasikal }\end{array}$ \\
\hline 1 & Keriasama & 80,76 & 82,05 & 96,15 & 100 \\
\hline 2 & Tanggung jawab & 81,41 & 79,48 & 90,38 & 100 \\
\hline 3 & Disiplin & 81,41 & 82,05 & 92,95 & 100 \\
\hline \multirow[t]{3}{*}{4} & Perbatian & 91,66 & 89,74 & 98,07 & 100 \\
\hline & Nilai Tertinggi & \multicolumn{2}{|c|}{100} & \multicolumn{2}{|c|}{100} \\
\hline & Nilai Terendah & \multicolumn{2}{|c|}{50} & \multicolumn{2}{|c|}{75} \\
\hline
\end{tabular}

Tabel 3 tentang perbandingan hasil belajar ranah afektif IPA pada siklus I dan siklus II menunjukkan adanya peningkatan. Data menunjukkan aspek kerjasama pada siklus I nilai rata-ratanya sebesar 80,76 kemudian meningkat pada siklus II nilai rata-ratanya menjadi 96,15. Ketuntasan klasikal meningkat dari $82,05 \%$ menjadi $100 \%$. Aspek tanggung jawab pada siklus I nilai rata-ratanya sebesar 81,41 meningkat pada siklus II menjadi 90,38, ketuntasan klasikal meningkat dari 79,48\% menjadi $100 \%$. Pada aspek disiplin siklus I nilai rata-ratanya sebesar 81,41 meningkat pada siklus II menjadi 92,95, ketuntasan klasikal meningkat dari $82,05 \%$ menjadi $100 \%$ dan pada aspek perhatian mengalami peningkatan secara drastis dengan nilai rata-rata 91,66 pada siklus I meningakat pada siklus II menjadi 98,07, ketuntasan klasikal meningkat dari 89,74\% menjadi 100\%. Dengan demikian terjadi peningkatan hasil belajar ranah afektif dari siklus I ke siklus II. Nilai tertinggi pada siklus I adalah 100, sementara nilai terendah yang diperoleh siswa adalah 50 meningkat pada siklus II nilai tertinggi yang diperoleh 100 dan nilai terendah menjadi 75 .

Tabel 4. Analisis Perbandingan Hasil Belajar Ranah Psikomotor IPA Siklus I dan Siklus II

\begin{tabular}{|c|c|c|c|c|c|}
\hline \multirow[t]{2}{*}{ No } & \multirow[t]{2}{*}{ Ketuntasan } & \multicolumn{2}{|c|}{ Siklus I } & \multicolumn{2}{|c|}{ Siklus II } \\
\hline & & $\begin{array}{c}\text { Nilai } \\
\text { Rata-rata }\end{array}$ & $\begin{array}{c}\text { Nilai } \\
\text { Klasikal }\end{array}$ & $\begin{array}{c}\text { Nilai } \\
\text { Rata-rata }\end{array}$ & $\begin{array}{l}\text { Nilai } \\
\text { Klasikal }\end{array}$ \\
\hline 1 & $\begin{array}{l}\text { Ketepatan dalam meniawab } \\
\text { pertanxaan }\end{array}$ & 85,89 & 82.05 & 94,87 & 100 \\
\hline 2 & $\begin{array}{l}\text { Ketelitian dalam menuliskan } \\
\text { jawaban }\end{array}$ & 85,26 & 76,92 & 96,15 & 100 \\
\hline 3 & $\begin{array}{l}\text { Kemampuan dalam menjawab } \\
\text { sesuai dengan alokasi waktu }\end{array}$ & 85,23 & 71,79 & 96,79 & 100 \\
\hline 4 & $\begin{array}{l}\text { Kemampuan dalam menjelaskan } \\
\text { materi }\end{array}$ & 83,33 & 84,61 & 92,56 & 100 \\
\hline & Nilai Tertinggi & \multicolumn{2}{|c|}{100} & \multicolumn{2}{|c|}{100} \\
\hline & Nilai Terendah & \multicolumn{2}{|c|}{50} & \multicolumn{2}{|c|}{75} \\
\hline
\end{tabular}

Tabel 4 menyajikan tentang perbandingan hasil belajar ranah psikomotor IPA siklus I dan siklus II. Data menunjukkan aspek ketepatan dalam menjawab pertanyaan pada siklus I dengan nilai rata-rata 85,89 meningkat menjadi 95,87 pada siklus II, ketuntasan klasikal sebesar $82,05 \%$ meningkat menjadi 
100. Aspek ketelitian dalam menuliskan jawaban dengan nilai rata-rata 85,26 meningkat menjadi 96,15 pada siklus II, ketuntasan klasikal 76,92\% meningkat menjadi 100\%. Aspek kemampuan dalam menjawab sesuai dengan alokasi waktu pada siklus I dengan rata-rata 85,23 meningkat pada siklus II menjadi 96,79 ketuntasan klasikal 71,79\% meningkat menjadi 100\% dan aspek kemampuan dalam menjelaskan materi pada siklus I dengan rata-rata 83,33 meningkat menjadi 96,79 pada siklus II, ketuntasan klasikal 84,61\% meningkat menjadi $100 \%$. Nilai terendah yang diperoleh siswa pada siklus I adalah 100 sementara nilai terendah 50 meningkat pada siklus II menjadi nilai tertinggi yang diperoleh 100, sementara nilai terendah 75. Hal tersebut menunjukkan adanya peningkatan hasil belajar ranah psikomotor pada pembelajaran IPA.

Penelitian tindakan kelas ini menekankan pada usaha perbaikan untuk dapat meningkatkan hasil belajar IPA pada siswa kelas V SD N Tegalrejo 01 dengan menggunakan model pembelajaran kooperatif tipe TGT sebagai solusi dari permasalahan yang sudah teridentifikasi. Keterlibatan siswa dalam proses pembelajaran dapat mempengaruhi hasil belajar siswa, sehingga dalam pembelajaran ini siswa dibagi menjadi kelompok-kelompok heterogen yang di dalamnya terdapat permainan akademik yang dapat membuat pembelajaran menjadi hidup, siswa tidak merasa bosan dan pembelajaran tidak lagi berpusat pada guru (teacher center oriented). Dalam kelompok siswa berperan sebagai tutor sebaya sehingga bisa belajar bersama dengan kelompok dalam kegiatan diskusi. Dalam hal ini melatih siswa untuk bersosialisi dengan orang lain, dapat saling bekerja sama dan melatih tanggung jawab. Setelah diskusi siswa melakukan permainan akademik sehingga siswa terlibat aktif dalam pembelajaran dan guru hanya berperan sebagai fasilitator serta mediator.

Keaktifan belajar siswa menunjukkan adanya peningkatan. Pada kondisi awal terdapat 11 siswa aktif dengan persentase 28,20\% meningkat pada siklus II menjadi 23 siswa aktif dengan persentase $58,97 \%$ dan mengalami peningkatan kembali pada siklus II menjadi 28 siswa aktif dengan persentase $71,79 \%$.

Hasil belajar ranah kognitif siklus I hasil belajar menunjukkan adanya peningkatan yang berarti. Pada kondisi awal rata-ratanya 70,12 dengan persentase ketuntasan 61,54\% pada siklus I nilai rataratanya meningkat menjadi 81,15 dengan persentase ketuntasan 82,05\% mengalami peningkatan kembali pada siklus II nilai rata-ratanya menjadi 90,25 dengan persentase ketuntasan $92,31 \%$.

Penelitian ini tidak hanya hasil belajar kognitif saja yang meningkat, akan tetapi hasil belajar ranah afektif dan ranah psikomotor pun meningkat. Pada siklus I hasil belajar ranah afektif yang diperoleh pada aspek kerjasama pada siklus I nilai rata-ratanya sebesar 80,76 kemudian meningkat pada siklus II nilai rata-ratanya menjadi 96,15. Ketuntasan klasikal meningkat dari 82,05\% menjadi $100 \%$. Aspek tanggung jawab pada siklus I nilai rata-ratanya sebesar 81,41 meningkat pada siklus II menjadi 90,38, ketuntasan klasikal meningkat dari 79,48\% menjadi 100\%. Pada aspek disiplin siklus I nilai rata-ratanya sebesar 81,41 meningkat pada siklus II menjadi 92,95, ketuntasan klasikal meningkat dari 82,05\% menjadi $100 \%$ dan pada aspek perhatian mengalami peningkatan secara drastis dengan nilai rata-rata 91,66 pada siklus I meningakat pada siklus II menjadi 98,07, ketuntasan klasikal meningkat dari 89,74\% menjadi 100\%. Dengan demikian terjadi peningkatan hasil belajar ranah afektif dari siklus I ke siklus II.

Hasil belajar ranah psikomotor terdapat empat aspek yaitu ketepatan dalam menjawab pertanyaan pada siklus I dengan nilai rata-rata 85,89 meningkat menjadi 95,87 pada siklus II, ketuntasan klasikal sebesar 82,05\% meningkat menjadi 100\%. Aspek ketelitian dalam menuliskan jawaban dengan nilai rata-rata 85,26 meningkat menjadi 96,15 pada siklus II, ketuntasan klasikal 76,92\% meningkat menjadi 100\%. Aspek kemampuan dalam menjawab sesuai dengan alokasi waktu pada siklus I dengan rata-rata 85,23 meningkat pada siklus II menjadi 96,79 ketuntasan klasikal 71,79\% meningkat menjadi $100 \%$ dan aspek kemampuan dalam menjelaskan materi pada siklus I dengan rata-rata 83,33 meningkat menjadi 96,79 pada siklus II, ketuntasan klasikal 84,61\% meningkat menjadi 100\%. Nilai terendah yang diperoleh siswa pada siklus I adalah 100 sementara nilai terendah 50 meningkat pada siklus II menjadi nilai tertinggi yang diperoleh 100, sementara nilai terendah 75.

Hasil penelitian ini menguatkan beberapa hasil penelitian yang ditemukan belakangan ini, diantaranya penelitian yang dilakukan oleh Saptayanti, dkk (2016) menunjukkan bahwa penerapan model pembelajaran teams games tournament berpengaruh secara signifikan terhadap hasil belajar Matematika siswa kelas V SD Gugus Singasari Kecamatan Pekutatan tahun pelajaran 2015/2016. Hasil penelitian lain menunjukkan bahwa: (1) terdapat perbedaan hasil belajar IPS antara siswa yang mendapat perlakuan pembelajaran dengan model pembelajaran kooperatif tipe TGT dengan siswa yang tidak mendapat perlakuan pembelajaran dengan model pembelajaran TGT dengan sig.0,046<0,05; (2) terdapat pengaruh interaksi antara model pembelajaran dan motivasi berprestasi terhadap hasil belajar IPS dengan sig.0,035<0,05; (3) pada siswa yang memiliki motivasi berprestasi tinggi, terdapat perbedaan hasil belajar IPS siswa antara siswa yang mendapat perlakuan model pembelajaran kooperatif tipe TGT dengan siswa yang tidak mendapat perlakuan model TGT dengan sig.0,004<0,05; dan (4) pada siswa yang

Wahyu Astuti, Firosalia Kristin (2017).

Jurnal Ilmiah Sekolah Dasar. Vol. 1 (3) pp.155-162. 
memiliki motivasi berprestasi rendah, terdapat perbedaan hasil belajar IPS siswa antara siswa yang mendapat perlakuan model pembelajaran kooperatif tipe TGT dengan siswa yang tidak mendapat perlakuan model TGT dengan sig.0,019<0,05, Sudha, dkk (2016). Penelitian lain yang menguatkan hasil penelitian ini adalah penelitian yang dilakukan oleh Agustini, dkk (2014) membuktikan bahwa model pembelajaran TGT berbantuan media flip chart berpengaruh signifikan terhadap hasil belajar siswa dalam pembelajaran IPA dibandingkan dengan model pembelajaran konvensional

Uraian di atas memberikan gambaran bahwa penerapan model pembelajaran tipe Teams Games Tournament (TGT) sangat efektif digunakan dalam pembelajaran IPA. Penerapan model pembelajaran kooperatif tipe TGT dalam penelitian ini terbukti dapat meningkatkan keaktifan dan hasil belajar siswa kelas V SD Negeri Tegalrejo 01 pada mata pelajaran IPA semester II Tahun Pelajaran 2016/2017.

\section{Simpulan dan Saran}

Penerapan model pembelajaran kooperatif tipe Teams Games Tournament (TGT) dapat meningkatkan keaktifan dan hasil belajar IPA siswa kelas V SD N Tegalrejo 01. Hal ini terlihat dari keaktifan siswa pra siklus 28,20\%, siklus I 58,97\% dan siklus II menjadi $71,79 \%$. Hasil belajar ranah kognitif pra siklus $61,54 \%$, pada siklus I menjadi $82,05 \%$ dan pada siklus II menjadi $92,31 \%$. Hasil belajar ranah afektif pada siklus I dan siklus II menunjukkan peningkatan rata-rata sikap aspek kerjasama 80 menjadi 96, aspek tanggung jawab 81 menjadi 90, aspek disiplin 81 menjadi 92, aspek perhatian 91 menjadi 98. Hasil belajar ranah psikomotor aspek ketepatan 85 menjadi 94, aspek ketelitian 85 menajadi 96, aspek kemampuan menjawab 85 menjadi 96, aspek kemampuan menjelaskan materi 83 menjadi 92. Hasil penelitian dapat disimpulkan bahwa penerapan model pembelajaran kooperatif tipe Teams Games Tournament (TGT) dapat meningkatkan keaktifan dan hasil belajar IPA siswa kelas V SD N Tegalrejo 01. Saran yang dapat diberikan berdasarkan penelitian ini adalah guru hendaknya menerapkan model pembelajaran yang bervariasi lagi dengan pembelajaran yang berpusat pada siswa sehingga pembelajaran dapat berjalan dengan baik dan efektif dan bagi siswa hendaknya lebih memperhatikan dan antusias dalam mengikuti pembelajaran.

\section{Daftar Pustaka}

Agustini, Md. , Kt.Dibia, Kd. Suartama. 2014. Pengaruh Model Pembelajaran Tgt Berbantuan Media Flip Chart Terhadap Hasil Belajar Ipa Siswa Kelas V Sd. Jurnal Mimbar PGSD Universitas Pendidikan Ganesha Jurusan PGSD Vol: 2 No: 1.

Ar Suherman Erman., dkk. 2003. Strategi Pembelajaran Matematika Kontemporer. Bandung: Universitas Pendidikan Indonesia

Aunurrahman. 2009. Belajar dan Pembelajaran. Bandung : Alfabeta.

Departemen Pendidikan Nasional. 2003. Undang-Undang Nomor 20 Tahun 2003. Tentang Sistem Pendidikan Nasional. Jakarta: Depdiknas.

Fathurrohman Muhammad. 2015. Model-Model Pembelajaran Inovatif.

Yogyakarta: ArRuzzmedia.

Hamdani. 2011. Strategi Belajar Mengajar. Bandung: Pustaka Setia.

Maharani, Okti Desta Tri \& Kristin, Firosalia. 2017. Peningkatan Keaktifan dan Hasil Belajar IPS Melalui Model Pembelajaran Kooperatif Tipe Make A Match. Wacana Akademika: Majalah Ilmiah Kependidikan, Vol 1(1) : 4-5.

Purwanto. 2011. Evaluasi Hasil Belajar. Yogyakarta: Pustaka Belajar.

Samatowa, Usman. 2011. Pembelajaran IPA di Sekolah Dasar. Jakarta: PT. Indeks

Slameto. 2003. Belajar dan faktor-faktor yang mempengaruhinya. Jakarta:

Rineka Cipta.

2015. Metodologi Penelitian dan Inovasi Pendidikan. Salatiga: Satya Wacana University Press.

Saptayanti, Gusti Ayu Kade Emi, I Made Citra Wibawa, Ketut Pudjawan. 2017. Pengaruh Model Pembelajaran Kooperatif Tipe Tgt (Teams Games Tournament) Terhadap Hasil Belajar Matematika. e-Journal PGSD Universitas Pendidikan Ganesha Jurusan PGSD Vol: 4 No: 1. 
Sudarti. 2015. Peningkatan Prestasi Belajar IPS Melalui Teams Games Tournament (TGT) Di Kelas V SD Negeri Gemaharjo Kecamatan Watulimo Kabupaten Trenggalek. Jurnal Pendidikan Profesional. Vol 4(2) : 182.

Sudha, I Kt., Kt. Gading, Ndara Tanggu Renda. 2016. Pengaruh Model Pembelajaran Teams Games Tournament Dan Motivasi Berprestasi Terhadap Hasil Belajar IPS Kelas IV. e-Journal PGSD Universitas Pendidikan Ganesha Jurusan PGSD Vol: 4 No: 1.

Tiya, Kadir. 2013. Penerapan Model Pembelajaran Kooperatif Tipe Teams Games Tournament (TGT) dalam Upaya Meningkatkan Hasil Belajar Matematika Siswa SMPN. Jurnal Pendidikan Matematika. Vol 4 : 181.

Trianto. 2011. Model Pembelajaran Terpadu. Jakarta : Bumi Aksara.

Widayanti, Eka Rizki, Slameto. 2016. Pengaruh Penerapan Metode Teams Games Tournament Berbantuan Permainan Dadu terhadap Hasil Belajar IPA. Scholaria. Vol 7(3) : 184-185. 